\title{
Evaluation of the Immunohistochemical Staining Pattern of the mTOR Signaling Proteins in Colorectal Cancers and Adenoma Lesions
}

Jin Mok Kim, Hyoun Wook Lee

Department of Pathology, Sungkunkwan University Samsung Changwon Hospital, Changwon, Korea

\section{대장암과 선종 병변에서 mTOR 신호 단백질의 면역조직화학 염색성 평가}

김진목, 이현욱

성균관대학교 삼성창원병원 병리과

\begin{abstract}
Changes in the mammalian target of the rapamycin (mTOR) signaling proteins have been observed in many types of cancer. Accordingly, these proteins have recently become an exciting new target for molecular therapeutics. This study examined the expression of an activated mTOR signaling protein in patients with colorectal adenocarcinoma (CRAC) and colorectal adenoma lesion. Immunohistochemical analysis was performed on human CRAC and adenoma for the mTOR signaling components, including mTOR, phosphorylation, and activation of S6 kinase (p70-S6K), S6 ribosomal protein (S6), and eukaryotic initiation factor 4E-binding protein (4EBP1). A total of 100 cases with colorectal adenocarcinoma (CARC; $N=40$ ), adenoma with high-grade intraepithelial neoplasms (HIN; $\mathrm{N}=30$ ), and adenoma with low-grade intraepithelial neoplasms ( $\mathrm{LIN} ; \mathrm{N}=30$ ) were enrolled in this study. p-mTOR expression was observed in 30 cases of the CRAC tissues (75\%), 9 cases of adenoma with HIN (30\%), and 2 cases of adenoma with LIN (7\%). In addition, p-S6 expression was observed in 22 cases of CRAC tissues (55\%), 8 cases of adenoma with HIN (27\%), and 3 cases of adenoma with LIN (10\%). A significant correlation was observed among the $\mathrm{p}$-mTOR, $\mathrm{p}-\mathrm{S} 6$ expression, and the adenoma-carcinoma sequence. Interestingly, the $\mathrm{p}-\mathrm{S} 6$ protein was activated more in early CRAC than in advanced CRAC.
\end{abstract}

Key words: Mammalian target of rapamycin, Colorectal adenocarcinoma, Adenoma, S6 ribosomal protein

This is an Open Access article distributed under the terms of the Creative Commons Attribution Non-Commercial License (http://creativecommons.org/licenses/by-nc/4.0) which permits unrestricted non-commercial use, distribution, and reproduction in any medium, provided the original work is properly cited.

Copyright (C) 2017 The Korean Society for Clinical Laboratory Science. All rights reserved.
Corresponding author: Jin Mok Kim Department of Pathology, Sungkyunkwan University Samsung Changwon Hospital, 158 Paryong-ro, Masanhoewon-gu, Changwon 51353, Korea

Tel: 82-55-233-5776

Fax: 82-55-233-5774

E-mail: bluemogi@naver.com

Received: October 20, 2017

Revised $1^{\text {st: }}$ November 2, 2017

Revised 2 ${ }^{\text {nd }}$ : November 9, 2017

Accepted: November 10, 2017

\section{INTRODUCTION}

The mTOR was identified in the budding yeast Saccharomyces cerevisiae during a screen for resistance to the immunosuppressant drug rapamycin [1]. It is a serinethreonine protein kinase that belongs to the phos- phoinositide 3-kinase-related kinase family. In mammalian cells, it has emerged as a critical effector in cell signaling pathways, which regulate cell growth and proliferation by integrating signals arising from growth factor, nutrients, and energy status [2].

According to the National Cancer Center, the incidence 
of colorectal cancer is steadily increasing and remains the third most prevalent cancer and the fourth most common cause of cancer death in Republic of Korea. Colorectal cancer usually proceeds stepwise and originates from adenoma, which is the mutation of tumor suppressor and tumorigenesis genes [3]. The term adenoma-carcinoma sequence might have been first used by Jack Mayo in 1951. This tumor progression model deduced from comparison of genetic alterations seen in normal colon epithelium, adenomas of progressively larger size, and malignancies [4]. Based on subsequent articles and research, transition from normal epithelium to adenoma and carcinoma is associated with acquired molecular events, including loss of methyl groups in DNA, activated oncogenes, such as $\mathrm{K}$-ras mutation and inactivation of $\mathrm{p} 53$ gene $[5,6]$. Thus, colonoscopy with detection and removal of adenomas is considered a powerful tool to reduce colorectal cancer (CRC) incidence in nowadays [7].

Although the adenoma-carcinoma sequence has not been proven directly, considerable indirect evidence from a range of epidemiological, clinical, histopathological, and genetic studies supports it. However, cell signal change was not analyzed in previous studies. Thus, this study aimed to evaluate the expression of cell signaling proteins, namely, p-mTOR, p70-S6K, p-S6, and p-4EBP1, in colorectal cancer tissues and the corresponding benign adenoma lesion in the colon.

\section{MATERIALS AND METHODS}

\section{Samples}

This study retrospectively examined surgical pathology data of SC Hospital in Changwon city from January 2011 to March 2012. FFPE (formalin fixed paraffin embedded) colon tissue samples, which were found to be adenoma with low-grade intraepithelial neoplasms (LIN; N=30), adenoma with high-grade intraepithelial neoplasms (HIN; $\mathrm{N}=30$ ), and colorectal adenocarcinoma (CRAC; $\mathrm{N}=40$ ), were selected.

\section{Antibodies}

All antibodies for immunohistochemistry were obtained from Cell Signal Technology. These antibodies included phospho-mTOR ${ }^{\text {Ser2448 }}$ rabbit monoclonal antibody, p70-S6 kinase rabbit monoclonal antibody, phospho-S6 $6^{\mathrm{Ser} 235 / 236}$ ribosomal protein polyclonal antibody, and phospho-4EBP $1^{\text {Thr37/46 }}$ rabbit monoclonal antibody (Table 1).

\section{Tissue array and immunohistochemistry}

The FFPE colon tissues were cut by $3 \mu \mathrm{m}$ and four cases (normal, LIN, HIN, and adenocarcinoma) were detached at once on one poly-1-lysine (Sigma, St Louis, MO)-coated slide. The tissues were deparaffinized in xylene and rehydrated in a descending ethanol series of graded alcohol to water. Immunohistochemical staining was performed using the DAKO EnVision Kit (Dako Corp., Carpinteria, $\mathrm{CA}$ ). Briefly, antigen retrieval was performed by autoclave at $105^{\circ} \mathrm{C}$ in citrate buffer for $13 \mathrm{~min}$. To block non-specific protein binding, sections were pre-incubated with a blocking solution (Ultra V Block, Lab Vision Corporation, Freemont, CA, USA), and the excess of these sections were removed. The sections were incubated overnight at room temperature with monoclonal antibodies diluted in the range of 1:50-1:100 in 0.05 M Tries-HCL+1\% bovine serum albumin against $\mathrm{p}-\mathrm{mTOR}, \mathrm{p} 70-\mathrm{S} 6 \mathrm{~K}, \mathrm{p}-\mathrm{S6}$, and $\mathrm{p}$-4EBP1 proteins. After three washes with phosphate-buffered saline (PBS), the sections were incubated for $30 \mathrm{~min}$ with a secondary antibody (DAKO EnVision detection reagent) and then washed three times with PBS. Lastly, peroxidase substrate 3, 3-diaminobenzidine tetrahydrochloride was added for staining. All sections were counterstained with Mayer's hematoxylin and observed by light microscopy. For negative controls, primary antibody

Table 1. Immunohistochemistry antibodies for paraffin embedded tissues and detection form, lastly dilution titer

\begin{tabular}{lcc}
\hline \multicolumn{1}{c}{$\mathrm{Ab}$} & Detection & Dilution titer \\
\hline mTOR & phospho-mTOR (Ser2448) & $1: 100$ \\
p70-S6K & p70 S6 kinase (49D7) & $1: 60$ \\
S6 & phospho-S6 ribosomal protein & $1: 50$ \\
& (Ser 235/236) & \\
4EBP1 & phospho-4EBP1 (Thr37/46) & $1: 100$ \\
\hline
\end{tabular}


was omitted from the protocol.

\section{Interpretation of immunohistochemical staining}

A independent pathologist with no prior knowledge of the clinical or pathological parameters evaluated the staining results. Slides were examined at $\times 200 \sim 400$, and at least four sections were observed in each case. Immunoreactivity for mTOR signaling Abs was evaluated using a previously described scoring system. The extent of staining was scored 0-100 according to the percentage of cytoplasmically stained mucosal cells. Staining intensity was scored as 0 (0\%), 1 (weak), 2 (medium), and 3 (strong). The final staining score was calculated by multiplying the intensity and extent scores; the final staining scores of $>30$ were considered positive. The mTOR expression was found in the membrane and the cytoplasm of the colorectal cancer cells but not in the normal mucosa and stromal cells.

\section{Statistical analysis}

One-way analysis of variance (ANOVA) was employed to assess the differential expression in the biomarker immunohistochemical scores in the three classified groups. Correlations between markers were calculated using the Pearson's correlation coefficient along with tests for significance. The comparison between $\mathrm{p}-\mathrm{mTOR}$ or $\mathrm{p}-\mathrm{S} 6$ activity and the clinical parameter was made by the Fisher's exact test. All tests were assessed at the 0.05 level of significance. Statistical computations were conducted using the statistical software SPSS version 12 (SPSS, Chicago, IL, USA).

\section{RESULTS}

\section{Clinical-pathologic characteristics}

All 100 cases of colorectal lesions were classified by pathologic stage and examined by histological type, tumor size, gender, and age. The polyp or tumor mean size and age were the greatest in the group of advanced CRAC. In the distribution of the sex ratio, the males were greater in number than the females in the four groups (Table 2).

\section{Expression of the mTOR signaling components}

Human colorectal adenoma with LIN, HIN, and CRC was analyzed by the activity of the mTOR signaling Abs. The positive products were stained brown, and the negative ones were not stained. In contrast to the paired normal mucosa, $\mathrm{p}-\mathrm{mTOR}^{\mathrm{Ser} 2448}, \mathrm{p} 70-\mathrm{S} 6 \mathrm{~K}$, and $\mathrm{p}-\mathrm{S} 6^{\mathrm{Ser} 235 / 236}$ were all predominantly expressed in the cytoplasm in the glandular elements of the adenomas. The $\mathrm{p}-4 \mathrm{EBP} 1^{\text {Thr37/46 }}$ expression was observed in the glandular elements of the adenomas with cytoplasmic and nuclear expressions (Figure 1). The $\mathrm{p}$-mTOR and $\mathrm{p}-\mathrm{S} 6$ expressions were sequentially increased in accordance with the cell signal from the adenoma with LIN to CRACs ( $p<0.01)$. Compared with HIN, they exhibited a lower expression in adenomas with LIN. Except for the p-4EBP1 ${ }^{\text {Thr37/46 }}$ expression, which was significantly higher in adenomas with HIN than in other groups $(p<0.05)$, the $\mathrm{p}$-mTOR and $\mathrm{p}$-S6 activities in LIN of the other two partners were similar to those of the paired normal mucosa. The p70-S6K expression had no significant difference among the three groups $(p>0.05)$. The expression patterns of $\mathrm{p}-\mathrm{mTOR}$ and $\mathrm{p}-\mathrm{S} 6$ were almost similar to that of the adenoma-carcinoma sequence

Table 2. Clinicopathologic characteristics of specimens used for immunohistochemistry analysis

\begin{tabular}{|c|c|c|c|c|c|c|}
\hline \multirow{2}{*}{ Stage } & \multicolumn{3}{|c|}{ Histological type } & \multirow{2}{*}{$\begin{array}{l}\text { Poylp or tumor size } \\
\text { (average) }\end{array}$} & \multirow{2}{*}{ Female/male } & \multirow{2}{*}{$\begin{array}{l}\text { Average age, y } \\
\text { (range) }\end{array}$} \\
\hline & TVA & $\mathrm{TA}$ & NC & & & \\
\hline LIN & 15 & 15 & 0 & 0.67 & $8 / 22$ & $60.5(41 \sim 76)$ \\
\hline HIN & 15 & 15 & 0 & 1.00 & $6 / 24$ & $58.1(43 \sim 81)$ \\
\hline Early CRAC & 5 & 10 & 5 & 2.24 & $6 / 14$ & $60.1(43 \sim 82)$ \\
\hline Advanced CRAC & 6 & 9 & 5 & 3.85 & $8 / 12$ & $71.2(56 \sim 85)$ \\
\hline
\end{tabular}

Abbreviations: TVA, Tubular villous adenoma; TA, Tubular adenoma; NC, Not classified; LIN, Low grade Intraepithelial Neoplasia; HIN, High grade Intraepithelial Neoplasia; CRAC, Colorectal adenocarcinoma; Early CRAC, infilteration of depth to subserosa; Advanced CRAC, infilteration of depth in serosa to muscle. 


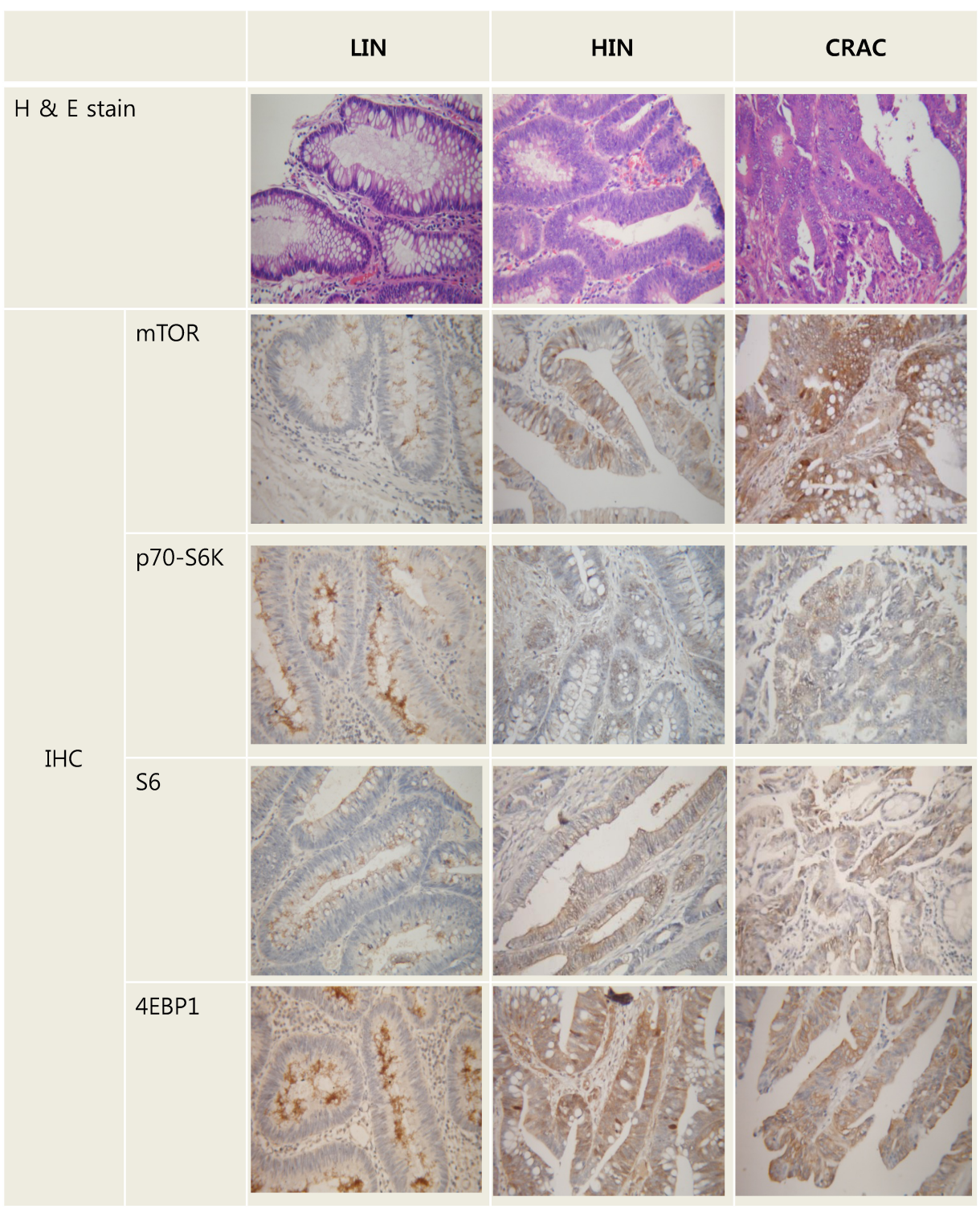

Figure 1. Expression of mTOR signaling proteins in colorectal adenomas and CRACs. All staining patterns were present in tumor cells as a brown color upon optical microscopy $(\times 200)$.
(Figure 2, Table 3).

\section{Correlation coefficients between the $p-m T O R$ and $\mathrm{p}-\mathrm{S} 6$ or $\mathrm{p}-4 \mathrm{EBP} 1$ activities}

We then analyzed the relationship between p-mTOR and $\mathrm{p}-\mathrm{S} 6$ or $\mathrm{p}$-4EBP1 activities using the Pearson's correlation coefficient test in adenomas to CRACs (Table 4). The correlation between mTOR and S6 was stronger than that between 4EBP1 in HIN and CRAC. The mTOR activity and $\mathrm{S} 6$ expression were moderately correlated in $\operatorname{HIN}\left(r_{s}=0.61 ; p<0.02\right)$ and $\operatorname{CRC}\left(r_{s}=0.59 ; p<0.02\right)$.

\section{Comparison between $\mathrm{p}-\mathrm{mTOR}$ or $\mathrm{p}-\mathrm{S} 6$ activity and the clinical parameter}

We investigated the correlation between the CRAC parameters and the $\mathrm{p}-\mathrm{mTOR}$ or $\mathrm{p}-\mathrm{S} 6$ expression by using Fisher's exact test (Table 5). The CRAC parameters included age, gender, depth, and lymph node metastasis. A relationship was found between depth and $\mathrm{p}-\mathrm{S} 6$ expression $(p<0.05)$.

\section{DISCUSSION}

Research on the relationship between intracellular 
signaling proteins and cancer has been actively conducted in various fields, It deals specifically with cell signaling and its relevance to various cancers and the usefulness of drugs to block overexpressed cellular signaling proteins [8-12]. The mTOR regulates protein synthesis through the phosphorylation of p70-S6k and 4EBP1. Phosphorylated 4EBP1 has a decreased affinity with eukaryotic translation

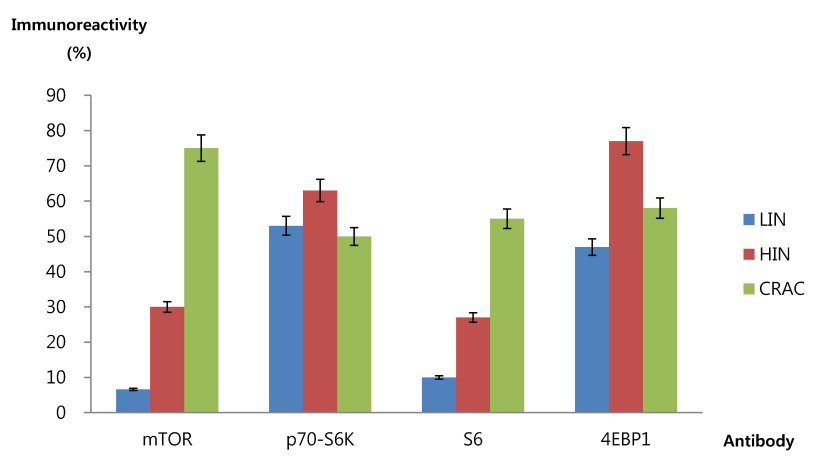

Figure 2. Immunohistochemical (IHC) analysis of Adenoma and CRACs group. Comparison of IHC scores for P-mTOR ${ }^{\text {Ser2448, }}$

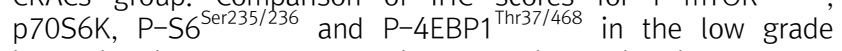
intraepithelial adenoma, the high grade intraepithelial adenoma and the colorectal adenocarcinoma. initiation factor 4E (eIF4E), so dissociates from it. Released eIF4E then binds to messenger ribonucleic acid (mRNA) cap structure, initiating protein translation in eukaryote. Thus overexpressed p-4EBP1 may be associated with increased protein synthesis (Figure 3) [13-17]. Therefore, the altered mTOR signal pathway can cause various type of cancer. So I examined the immunohistochemical staining pattern of how it relates to adenoma-carcinoma sequence in colon.

In this study, we showed for the first time that the p-mTOR expression was much higher in CRAC (75\%) than in either paired HIN (30\%) or LIN (7\%). Also the p-S6

Table 3. Phospho-mTORs immunoreactivity in CRCs and colorectal adenomas

\begin{tabular}{lcccc}
\hline p-mTORs & $\begin{array}{c}\text { Adenomas, LIN } \\
(\mathrm{N}=30)\end{array}$ & $\begin{array}{c}\text { Adenomas, HIN } \\
(\mathrm{N}=30)\end{array}$ & $\begin{array}{c}\text { CRCs } \\
(\mathrm{N}=40)\end{array}$ & $p$-value \\
\hline mTOR & $2(7 \%)$ & $9(30 \%)$ & $30(75 \%)$ & 0.000 \\
p70-S6K & $16(53 \%)$ & $19(63 \%)$ & $20(50 \%)$ & 0.795 \\
S6 & $3(10 \%)$ & $8(27 \%)$ & $22(55 \%)$ & 0.000 \\
4EBP1 & $14(47 \%)$ & $23(77 \%)$ & $23(58 \%)$ & 0.049 \\
\hline
\end{tabular}

Number of positive cases and the corresponding percentage.

Table 4. Correlation coefficients between $\mathrm{p}-\mathrm{mTOR}$ proteins and $\mathrm{p}-\mathrm{S} 6$ or $\mathrm{p}-4 \mathrm{EBP} 1$

\begin{tabular}{|c|c|c|c|c|c|c|}
\hline & \multicolumn{2}{|c|}{ Low-grade adenoma } & \multicolumn{2}{|c|}{ High grade adenoma } & \multicolumn{2}{|c|}{ Colorectal adenocarcinoma } \\
\hline & Correlation coefficient & $p$-value & Correlation coefficient & $p$-value & Correlation coefficient & $p$-value \\
\hline \multicolumn{7}{|l|}{ P-mTOR } \\
\hline P-S6 & 0.061968 & 0.7449 & 0.606843 & $<0.02$ & 0.592419 & $<0.02$ \\
\hline P-4EBP1 & 0.239476 & 0.2024 & 0.308709 & 0.0969 & 0.326132 & $<0.05$ \\
\hline
\end{tabular}

The significant correlation between the p-mTOR activity score and the p-S6 activity was moderate in the CRAC and HIN.

Table 5. The comparisons between p-mTOR or p-S6 immunoreactivity and clinical parameters in CRAC tissues

\begin{tabular}{|c|c|c|c|c|c|c|c|}
\hline \multirow{2}{*}{ Clinicopathological parameters } & \multirow{2}{*}{$\begin{array}{l}\text { Case } \\
\text { number }\end{array}$} & \multicolumn{3}{|c|}{$\mathrm{p}-\mathrm{mTOR}$} & \multicolumn{3}{|c|}{$\mathrm{p}-56$} \\
\hline & & Pos. & Neg. & $p$ & Pos. & Neg. & $p$ \\
\hline Age $(y r$, median $=67.5$, range $=85-41)$ & & & & 0.731 & & & 0.110 \\
\hline$<67.5$ & 22 & 17 & 5 & & 15 & 7 & \\
\hline$>67.5$ & 18 & 13 & 5 & & 7 & 11 & \\
\hline Gender & & & & 0.231 & & & 0.491 \\
\hline Male & 26 & 20 & 6 & & 18 & 8 & \\
\hline Femal & 14 & 10 & 4 & & 8 & 6 & \\
\hline Depth of infiltration & & & & 0.473 & & & $<0.05$ \\
\hline $\mathrm{T} 1 \sim \mathrm{T} 2$ & 21 & 16 & 5 & & 17 & 4 & \\
\hline $\mathrm{T} 3 \sim \mathrm{T} 4$ & 19 & 14 & 5 & & 5 & 14 & \\
\hline Lymph node metastasis & & & & 0.642 & & & 0.604 \\
\hline Yes & 11 & 5 & 6 & & 5 & 6 & \\
\hline No & 9 & 7 & 2 & & 6 & 3 & \\
\hline
\end{tabular}

Abbreviations: Pos, positive; Neg, negative. 


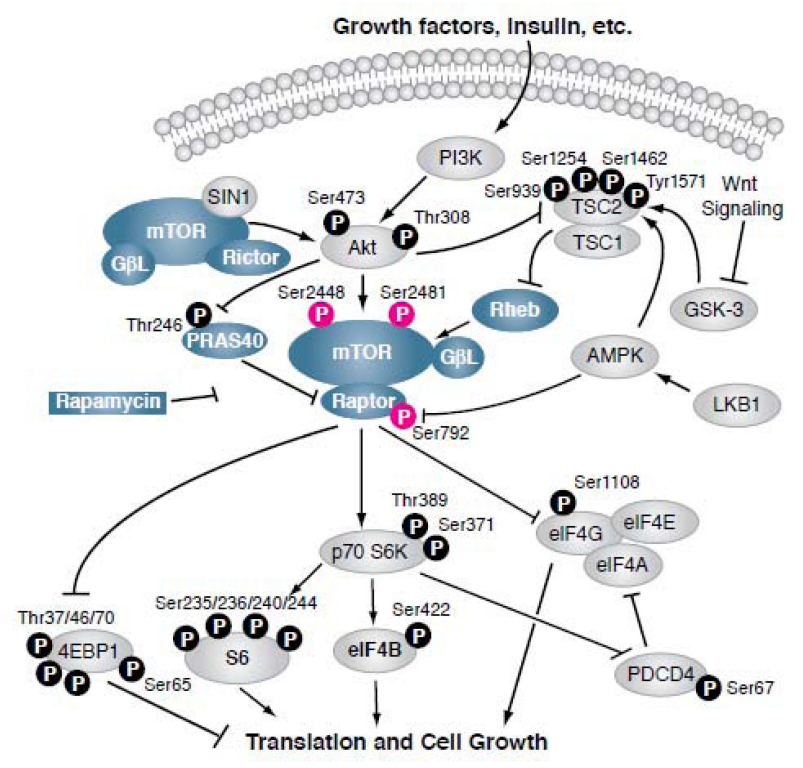

Figure 3. mTOR signaling schematic diagram by Cell Signaling Technology Incorporation. mTOR is phosphorylated at Ser2448 via the PI3 kinase/Akt signaling pathway and autophosphorylated at Ser2481. mTOR plays a key role in cellular growth and homeostasis and its regulation is frequently altered in tumors.

expression rate was similar to that. These results support the notion that the mTOR signaling proteins activity increased with the cell proliferation and the sequence for colorectal carcinogenesis is a progression from adenoma via intestinal dysplasia, with the subsequent development of invasive carcinoma [2,3,9].

However, the relationship between the p70-S6K and the three groups showed no significant changes ( $p>0.05)$, as the p70-S6K Ab was detected not only with the phosphorylated form but also with total proteins. Unfortunately, the $\mathrm{p}-4 \mathrm{EBP} 1$ activity was the highest in the HIN group (77\%), the second in the CRAC (57\%), the lowest in the LIN (47\%). Several studies have shown a slightly different result from the increase in $\mathrm{p}-4 \mathrm{EBP} 1$, which frees eIF4E to promote protein translation in cancer [18,19]. Future research is needed to confirm our findings and to identify the 4EBP1 activation mechanism and the potential pathogenic role in CRAC.

For the second time, the significant correlation between the $\mathrm{p}$-mTOR activity score and the $\mathrm{p}-\mathrm{S} 6$ activity was moderate in the CRAC and HIN. This is a clear indication that mTOR cell signaling target is $\mathrm{S} 6[13,14]$.

For the last time, we utilized the clinical significance of
p-mTOR and $\mathrm{p}-\mathrm{S} 6$ expressions in CRACs. This study obtained a unique result: $\mathrm{p}$-S6 expression was significantly related to a small invasion depth. That is, the $\mathrm{S} 6$ proteins had low activity in the progress toward CRAC. Therefore, p-mTOR and p-S6 are thought to be important immunohistochemical markers for cancer diagnosis. In particular, p-S6 may be useful for early cancer diagnosis.

The $\mathrm{p}-\mathrm{mTOR}$ and $\mathrm{p}-\mathrm{S} 6$ expressions were significantly over-activated in the CRACs than in the LIN adenomas. Moreover, the expression levels of the mTOR and S6 were stepwise increased with the adenoma-carcinoma sequence. We propose that CRAC is closely correlated with adenoma in the colon, followed by changes in mTOR signaling proteins.

\section{요 약}

mTOR 신호전달 단백질의 변화는 다양한 종류의 암에서 관 찰 되었다. 따라서 이들 단백질은 최근에 암 치료제에 대한 새롭 고 흥미로운 표적이 되고 있다. 우리는 대장암과 선종 환자의 $\mathrm{mTOR}$ 세포신호의 활성도를 조사하였다. 면역조직화학적 방 법으로 대장암과 선종의 세포신호 단백질 성분인 $\mathrm{mTOR}$, p70-S6K, S6, 4EBP1 발현을 분석하였다. 이번 연구는 모두 100 개의 예를 악성(Colorectal Adenocarcinoma, CRAC) 40 건, 고등급 선종(Adenoma with High grade intraepithelial neoplasms, HIN) 30건, 저등급 선종(Adenoma with Low-grade intraepithelial neoplasms, LIN) 30건으로 분류하여 진행하였 다. p-mTOR의 발현률은 $\operatorname{LIN~7\% ,~HIN~30\% ,~CRAC~75\% ㅇㅕㅆㄱㅗ~}$ p-S6의 발현률 또한 LIN 10\%, HIN 27\%, CRAC 55\%였다. $\mathrm{p}$-mTOR, $\mathrm{p}-\mathrm{S} 6$ 의 발현과 선종-선암 연속성은 중요한 상관관 계 있다는 것이 발견되었다. 그리고 흥미롭게도 $\mathrm{p}-\mathrm{S} 6$ 발현률은 진행암보다 초기암에서 더 높았다.

Acknowledgements: None

Funding: None

Conflict of interest: None

\section{REFERENCES}

1. Brown EJ, Albers MW, Shin TB, Ichikawa K, Keith CT, Lane WS, et al. "A mammalian protein targeted by G 1-arresting rapamycin-receptor complex". Nature. 1994;369(6483):756-758. 
2. Kim, DH, Sarbassov DD, Ali, SM, King JE, Latek RR, Erdjument-Bromage $\mathrm{H}$, et al. mTOR interacts with raptor to form a nutrient-sensitive complex that signals to the cell growth machinery. Cell. 2002;110(2):163-176.

3. Hermsen M, Postma C, Baak J, Weiss M, Rapallo A, Sciutto A, et al. Colorectal adenoma to carcinoma progression follows multiple pathways of chromosomal instability. Gastroenterology. 2002;123(4):1109-1119.

4. Jackman RJ, Mayo CW. The adenoma-carcinoma sequence in cancer of the colon. Surg Gynecol Obstet. 1951;93(3):327-330.

5. Nagel R, le Sage C, Diosdado B, van der Waal M, Oude Vrielink JAF, Bolijn A, et al. Regulation of the adenomatous polyposis coli gene by the miR-135 family in colorectal cancer. Cancer Res. 2008;68(14):5795-5802.

6. Toll AD, Fabius D, Hyslop T, Pequignot E, DiMarino AJ, Infantolino A, et al. Prognostic significance of high-grade dysplasia in colorectal adenomas. Colorectal Dis. 2011;13(4): 370-373.

7. Brenner H, Chang-Claude J, Seiler CM, Rickert A, Hoffmeister M. Protection from colorectal cancer after colonoscopy. Ann Intern Med. 2011;154(1):22-30.

8. Mamane Y, Petroulakis E, LeBacquer O, Sonenberg N. mTOR, translation initiation and cancer. Oncogene. 2006;25(48): 6416-6422.

9. Tee AR, Blenis J. mTOR, translational control and human disease. Semin Cell Dev Biol. 2005;16(1):29-37.

10. Noh WC, Kim YH, Kim MS, Koh JS, Kim HA, Moon NM, et al. Activation of the mTOR signaling pathway in breast cancer and its correlation with the clinicopathologic variables. Breast Cancer Res Treat. 2008;1109(3):477-483
11. No JH, Jeon YT, Park IA, Kim YB, Kim JW, Park NH, et al. Activation of mTOR signaling pathway associated with adverse prognostic factors of epithelial ovarian cancer. Gynecol Oncol. 2011;121(1):8-12.

12. Faivre S, Kroemer G, Raymond E. "Current development of mTOR inhibitors as anticancer agents". Nat Rev Drug Discov. 2006;5(8):671-88.

13. Fingar DC, Salama S, Tsou C, Harlow E, Blenis J. Mammalian cell size is controlled by mTOR and its downstream targets S6K1 and 4EBP1/eIF4E. Genes Dev. 2002;16(12):1472-1487.

14. Brown EJ, Beal PA, Keith CT, Chen J, Shin, TB, Schreiber, SL. Control of p70 s6 kinase by kinase activity of FRAP in vivo. Nature. 1995;377(6548):441-446.

15. Burnett PE, Barrow RK, Cohen NA, Snyder SH, Sabatini DM. RAFT1 phosphorylation of the translational regulators p70 S6 kinase and 4E-BP1. Proc Natl Acad Sci. 1998;95(4):1432-1437

16. Gingras AC, Gygi SP, Raught B, Polakiewicz RD, Abraham RT, Hoekstra, M.F. et al. Regulation of 4E-BP1 phosphorylation: A novel two step mechanism. Genes Dev. 1999;13:1422-1437.

17. Inoki K, Ouyang H, Li Y, Guan KL. Signaling by target of rapamycin proteins in cell growth control. Micro Mol Biol Rev. 2005;69(1):79-100.

18. Lazaris-Karatzas A, Montine KS, Sonenberg N. Malignant transformation by a eukaryotic initiation factor subunit that binds to mRNA cap. Nature. 1990;345(6275):544-7.

19. Graff JR, Boghaert ER, DeBenedetti A, Tudor DM, Zimmer SG. Reduction of translation initiation factor $4 \mathrm{E}$ reduces tumor growth, invasion and metastasis of ras transformed cloned rat embryo fibroblast. Int J Cancer. 1995;60(17):255-63. 